\title{
The Societas Unius Personae (SUP): A “Passport" for Job Creation and Growth
}

\section{Pierre-Henri Conac ${ }^{1}$}

Professor of Company Law at the University of Luxembourg. The author was a member of the Reflection Group on the future of www.degruyter.com uses cookies, tags, and tracking settings to store information that help give you the very best browsing experience.

To understand more about cookies, tags, and tracking, see our Privacy Statement

I accept all cookies for the De Gruyter Online site

The Societas Unius Personae (SUP):

A "Passport" for Job Creation and Growth

by

Pierre-Henri Conac*

\begin{abstract}
The proposal by tbe European Commission of a direcrive on single-member private limited liability companies of 9 April 2014 is designed to facilitate cross-border acrivities of enterprises, especially small axd medium-sized enterprises (SMEs) by requesting Member States to provide a company form called the Societas Unius Personac (SUP) that wauld be set wp online and would follow harmonised rules on key isses. Therefore, the SUP is a "passport" to facilitate the establisbment of companies in orher Member States. By facilitating exports and activities in otber Member States, the SUP would contribute to job creation and growtb in Europe. It would also be an internal "passport" as it wonld facilatate tbe creation of companies within Member States since it liberalises tbe rules on capital and forces online creation. The SUP would also significantly facilitate the cross-bonder fonctioning of groups, exactily like the Societas Privata Europed (SPE) - wbich the SUP replaces - was desigued to achieve. However, the approach adopted by the Commission is innovative as it does not seek to create a supranational company like the SPE. Criticism of the SUP fockses on its innodarive legal basis and content. However, these criticisms, even while addressing odid concerns, ari exaggerated or simply wnfounded. For example, critics of the oprion to separate the statwrory seat from the real seat is anderstandable, at least from a political perspectioe, and has been addressed. The Noocmber amended oersion in the Couscil bas introduced the right for the Member States to impose the real seat. This should belp alleviate concems that the SUP would be used to circumvent co-determitation.
\end{abstract}

Table of Contents $\quad$ ECFR 2015, 139-176

\footnotetext{
I. Introduction .

II. A passport for the cross-border establishment and functioning of companies 144

1. A passport for the establishment of companies ........... 144

2. A passport for the cross-border functioning of companies . . . . . . 152

III. A secure company law only passport . . . . . . . . . . . . . . 164

1. A secure passport ....................... $16 . \ldots$

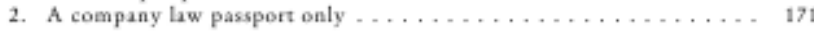

IV. Conclusion . . . . . . . . . . . . . . . . . 174

Professor of Company Law at the University of Luxembourg. The author was a member of the Reflection Group on the future of EU company law of 2011 which recommended the introduction of an harmonised single-member private limited liability company. $\mathrm{He}$ is currently a member of the Informal Company Law Expert Group (ICLEG).
}

Citation Information: European Company and Financial Law Review. Volume 12, Issue 2, Pages 139-176, ISSN (Online) 16132556, ISSN (Print) 1613-2548, DOI: 10.1515/ecfr-2015-0139, July 2015

Request Permissions

\section{Publication History}

Published Online: 